Relations industrielles

Industrial Relations

\title{
Labor Relations and Collective Bargaining, Text and Case, by Max G. Wortman Jr. and George C. Witteried, Boston, Allyn and Bacon, 1969, 388 pp.
}

\section{Jean Bernier}

Volume 25, numéro 2, 1970

URI : https://id.erudit.org/iderudit/028139ar

DOI : https://doi.org/10.7202/028139ar

Aller au sommaire du numéro

Éditeur(s)

Département des relations industrielles de l'Université Laval

ISSN

0034-379X (imprimé)

1703-8138 (numérique)

Découvrir la revue

Citer ce compte rendu

Bernier, J. (1970). Compte rendu de [Labor Relations and Collective Bargaining, Text and Case, by Max G. Wortman Jr. and George C. Witteried, Boston, Allyn and Bacon, 1969, 388 pp.] Relations industrielles / Industrial Relations, 25(2), 382-383. https://doi.org/10.7202/028139ar

Tous droits réservés @ Département des relations industrielles de l'Université Laval, 1970
Ce document est protégé par la loi sur le droit d'auteur. L’utilisation des services d’Érudit (y compris la reproduction) est assujettie à sa politique d'utilisation que vous pouvez consulter en ligne.

https://apropos.erudit.org/fr/usagers/politique-dutilisation/ 
With supervisory mobility what it is today, this study illustrates in a specific way, the general problems managers must face when transfers become a way of corporate life.

\section{Joan SICHEL}

\section{Automation: Threat or Promise ? - Im-} pact and Implications in Australia, by G.W. Ford, ed., Law Book Co. Ltd., 1969, 214 pp.

Ce volume est un compte-rendu d'un symposium tenu par l'Association pour l'avancement des sciences de l'Australie et de la Nouvelle-Zélande. L'année exacte n'est pas mentionnée mais il semblerait que le sous-comité sur l'automation ait commencé son travail au cours de l'année 1966.

En choisissant un sujet aussi vaste, il est facile de comprendre pourquoi on a tenté à la fois de définir le phénomène de l'automation et de décrire ses implications socio-économiques, au risque de demeurer dans des généralités.

Les exposés, pour la plupart, abordent des points très discutés tels que les effets de l'automation sur l'éducation, la formation professionnelle, l'emploi, le syndicalisme, le climat des relations patronales-ouvrières, etc. En plus de décrire les effets, les conférenciers indiquent les différentes avenues que des recherches subséquentes pourraient emprunter.

Ces exposés théoriques sont suivis de quelques études de cas décrivant avec assez de précision les étapes de l'introduction d'appareils automatiques dans le domaine des communications et de la distribution du gaz et de l'électricité.

Les observations et les réflexions des conférenciers sur les implications de l'automation rejoignent celles des chercheurs nord-américains. Ceci nous amène à conclure que les effets de l'automation demeurent passablement similaires quoique leur intensité varie lorsqu'on passe d'un pays industrialisé à un autre.

C'est un volume qui se lit facilement puisque les exposés sont regroupés sous le thème qui leur est commun. Chaque thème abordé constitue une partie avec des liens établis par des conférenciers et une conclusion rédigée par $M$. Davenport, vice-président de l'Association.

\section{Laurent BELANGER}

Labor Relations and Collective Bargaining, Text and Case, by Max G. Wortman Jr. and George C. Witteried, Boston, Allyn and Bacon, 1969, 388 pp.

Ce livre constitue un instrument pédagogique de première main qui s'inscrit dans les perspectives les plus récentes de l'enseignement en relations industrielles. Il présente, en plus d'un cadre de référence qu'on aurait souhaité un peu plus élaboré, une sélection importante de cas vécus illustrant les différents problèmes qui résultent de la négociation et de l'application de la convention collective.

L'étude et la discussion de ces cas par les étudiants et les professeurs devient un complément intéressant aux enseignements théoriques sur la convention collective en ce qu'ils permettent le contact avec un certain nombre de situations vécues par les parties elles-mêmes.

Il importe de souligner que les cas choisis couvrent une grande variété de problèmes. D'une part, des problèmes que l'on pourrait qualifier de «traditionnels $\gg$ tels que la détermination de l'unité de négociation, la procédure des griefs, les heures de travail, les salaires, etc. D'autre part, on fait place, et c'est là l'un des mérites de l'ouvrage, à des situations qui naissent du développement industriel dans une économie moderne; citons notamment les avantages sociaux, les mesures de protection des salariés en cas de changements technologiques, la question des sous-contrats, etc.

Dans la présentation des «cas», on essaie de reconstituer le mieux possible le contexte dans lequel ils se sont produits. De plus, pour faciliter la discussion, les auteurs proposent une série de questions pertinentes à chaque problème.

S'il s'agit d'un ouvrage à caractère plutôt pratique que théorique, il serait erroné d'affirmer qu'il a été conçu sans référence à des réflexions théoriques. 
En effet, à la suite de la présentation de chaque cas, on trouve une abondante bibliographie, de sorte que l'étudiant ou le professeur qui veut replacer la discussion dans un cadre plus théorique trouve là nombre de références utiles.

\section{Jean BERNIER}

Coalition Bargaining : A Study of Union Tactics and Public Policy, by William N. Chernish Philadelphia: University of Pennsylvania Press, 1969. This study is Number 45 in the series published by the Industrial Research Unit, Department of Industry, Wharton School of Finance and Commerce, University of Pennsylvania, $269 \mathrm{pp}$.

This book provides the first in depth study on coalition bargaining by an author whose academic credentials are impressive. Part One provides the background material «deemed appropriate to coalition bargaining, and develops the nature and operation of the coalition concept. It contains an overall view of the reasons that coalitions come about, and gives a general picture of how the coalitions are organized and how they operate.

«Part Two deals with the significant cases in coalition bargaining. Contained here are examinations of the coalitions which faced American-Standard, JohnsManville, American Home Products, General Electric and Westinghouse, Union Carbide, $3 \mathrm{M}$, the nonferrous industry, and several others. From these cases it is possible to gain a more detailed picture of the operation and impact of coalitions, and to begin to become aware of the variety of approaches possible by the unions.

«Part Three examines first the public policy implications of the coalition concept, and treats the problems brought about for both companies and the public as a result of the coalition situations. Then the final chapter attempts to examine the overall course of coalitions, and to speculate somewhat as to the future. of such bargaining. $\gg$ (p.x.)
The current coalition bargaining programmes have been under the sponsorship of the Collective Bargaining Section of the Industrial Union Department, AFL-CIO. Until 1964, the IUD had been concerned generally with organizational efforts for industrial unions, when «a special division was created by the IUD whose primary task was to be the development of coalition bargaining 》. (p. 4.)

Coalition bargaining is «the joining together of a number of local unions, having different international affiliations, for the purpose of bargaining with a company of an industry as a single unit. It is a form of joint bargaining which seeks to increase union bargaining power in dealing with a firm that has several locations which are represented by different unions, and which usually has plants that are able to substitute production, or which deal in different markets...

«...Coalition bargaining occurs as a union attempts to gain greater bargaining leverage in order to deal with a company whose structure makes it able to successfully stand against a single plant strike. The conglomerate corporation has been cited as one example of the sort of company which unions seek to engage in coalition bargaining because they are not able to extract sizable gains through existing bargaining relationships. In fact, the concept of coalition bargaining is one that seeks to enhance union economic strength in dealing with any firm which operates more than a single plant, and where employees are represented by more than one international union $»$. (pp. 5-6)

It is the rise of the conglomerate corporation that has «been the most important factor in bringing about a restructuring of the collective bargaining programs on the part of the AFL-CIO unions ». This is an expedient method for increasing union bargaining strength.

The techniques of the IUD are demonstrated in the discussion of the case studies where coalition bargaining was introduced. One significant demand has 